\title{
Article
}

Doi 10.5943/sif/4/1/7

\section{Paoayensis aquatica sp. nov. (Ascomycetes) on submerged wood from the River Tapti, Maharashtra, India}

\author{
Borse BD $^{1}$ and Pawar NS \\ ${ }^{1}$ N.S. S. Dhule's U. P. Arts and Science College, Dahiwel, Dhule, M.S. \\ ${ }^{2}$ S.S.V.P. S. Dhule's Arts, Com. and Sci. College, Sindkheda, Dhule, M.S.
}

Borse BD, Pawar NS 2019 - Paoayensis aquatica sp. nov. (Ascomycetes), on a submerged wood from the River Tapti, Maharashtra, India. Studies in Fungi 4(1), 50-53, Doi 10.5943/sif/4/1/7

\begin{abstract}
A new fungus was collected on submerged wood from a freshwater stream in Maharashtra at Western Ghats is described here as P. aquatica. The new ascomycete fungus differs from the type and only species in the genus, $P$. lignicola, by size and characteristics of ascomata, asci and ascospores. This is the first record of the genus Paoayensis from India.
\end{abstract}

Key words - biodiversity - freshwater - systematic - taxonomy

\section{Introduction}

Freshwater ascomycetes are defined as ascomycetous fungi which have been recorded in freshwater lentic and lotic habitats and which complete part, or the whole of their lifecycle within freshwater environment, playing an important role in recycling organic matter (Shearer 1993, Wong et al. 1998), and include ascomycetes and their anamorphs that grow on submerged wood, leaves and asexual spores found in foam samples (Cai et al. 2006, Vijaykrishna et al. 2006). Shearer (1993) listed 288 species of ascomycetes that had been recorded from freshwater habitats; this number has grown to 622 (Cai et al. 2014, Shearer et al. 2014). Many new taxa of freshwater ascomycetes have since been described including new genera and species (Baschien \& Hyde 2018, Bao et al. 2018, Li et al. 2017, Lin et al. 2018, Luo et al. 2018, Zhang et al. 2017). In India, studies on freshwater ascomycetes (69 sp.) were compiled by Borse et al. (2014, 2016, 2017).

The genus Paoayensis typified by Paoayensis lignicola Cabanela et al. (2007) is monotypic genus in Pezizomycotina, Sordariomycetes, Sordariomycetidae, and Annulatascaceae. The type species was reported from submerged wood in freshwater lentic habitat (Paoay Lake), in the Philippines. In this paper, we describe and illustrate a new species of Paoayensis which was found on submerged wood from a freshwater stream in India.

\section{Materials \& Methods}

Ascomata were observed on the submerged decaying wood under a stereo-zoom microscope. Asci and ascospores were mounted in lactic acid with cotton blue and measured using an ocular micrometer with 25 observations per structure. The holotype specimen (slides) is deposited in the Herbarium Cryptogamie Indiae Orientalis (H.C.I.O.), Division of mycology and plant Pathology, I.A.R.I. Pusa Campus, New Delhi, India (Holotype, HCIO no 52061).

\section{Results}


Paoayensis aquatica Borse and N.S. Pawar, sp. nov.

MycoBank MB829044

Etymology - from the Latin aquatica meaning 'growing in water'

Ascomata: 700-1000 $\mu \mathrm{m}$ high, 800-1000 $\mu \mathrm{m}$ diam, immersed, slightly erumpent through the host surface, papilla only visible, globose to obpyriform, in small valsoid groups with common ostiole, developing beneath a dark brown to black extensive pseudostroma. Ostiole: central, short, brownish-black and periphysate. Peridium: comprising several layers of light brown to brown cells which are darker externally and lighter to hyaline and compressed internally. Paraphyses: tapering distally, septate, rarely branching and early deliquescing. Asci: 85-170 × 40-65 $\mu \mathrm{m}$, 8-spored, unitunicate, clavate, short pedicellate, apical apparatus of the asci was not observed as they are deliquescing and rarely seen. Ascospores: 50-80 × 20-38 $\mu \mathrm{m}$, overlapping, lemon form, 1-3-septate, asymmetrical, base conical, apex rounded, first septum formed at the center and second and third septa formed simultaneously near the conical base and rounded apex, brown, dark-brown at maturity, germ slit 10-12 $\mu \mathrm{m}$ long, not full length, arising from the base, perpendicular to the ascospore, smooth-walled, and no sheath or appendages observed in aqueous India ink.

Anamorph - not observed.

Known distribution - tropical regions of India.

Material examined - India, Maharashtra, Sonewadi (Sindkheda, Dhule), on submerged decorticated Wood from Tapti River, 15 Aug 2015, B.D. Borse (Holotype, HCIO no 52061).

\section{Kye to Paoayensis species}

1. Asci 2-6-spored P. lignícola

2. Asci 8-spored P. aquatica

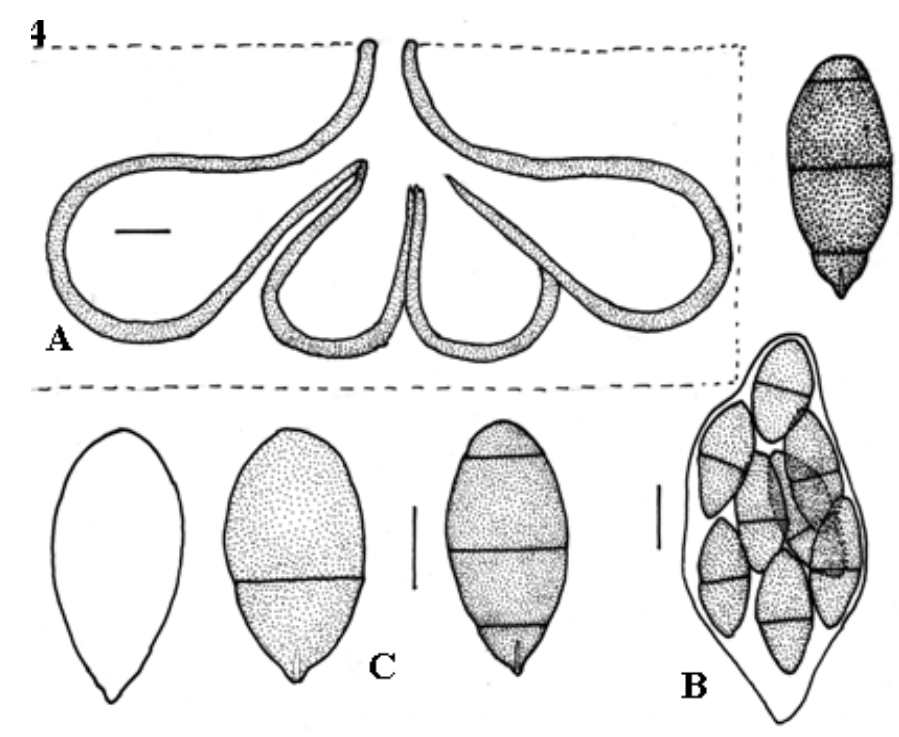

Fig. 1 - Line Drawings: A Ascomata. B Asci. C Ascospores.

\section{Discussion}

The general characteristics of the present collection fit within the concept of the monotypic genus Paoayensis (Cabanela et al. 2007). Paoayensis aquatica is differs markedly from the type species $P$. lignicola as data provided in the Table1. The ascomata and asci of the $P$. aquatica are larger than those of $P$. lignicola. Asci of the $P$. lignicola are 2-6-spored and are always 8-spored in $P$. aquatica Ascospores of $P$. lignicola are wider than $P$. aquatica. In $P$. aquatica first septum formed at the center and second and third septa formed simultaneously near the conical base and rounded apex which is similar to P. lignicola (noted from microphotographs). This is the first record of the genus Paoayensis from India. 

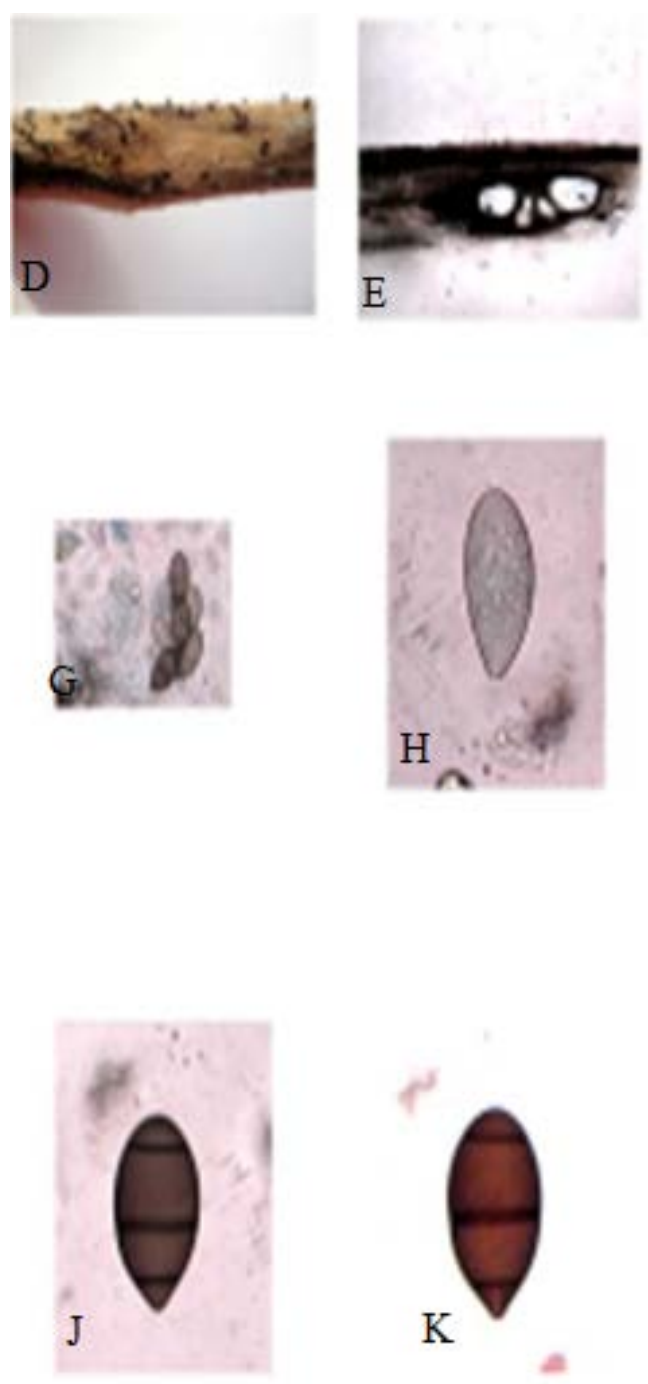
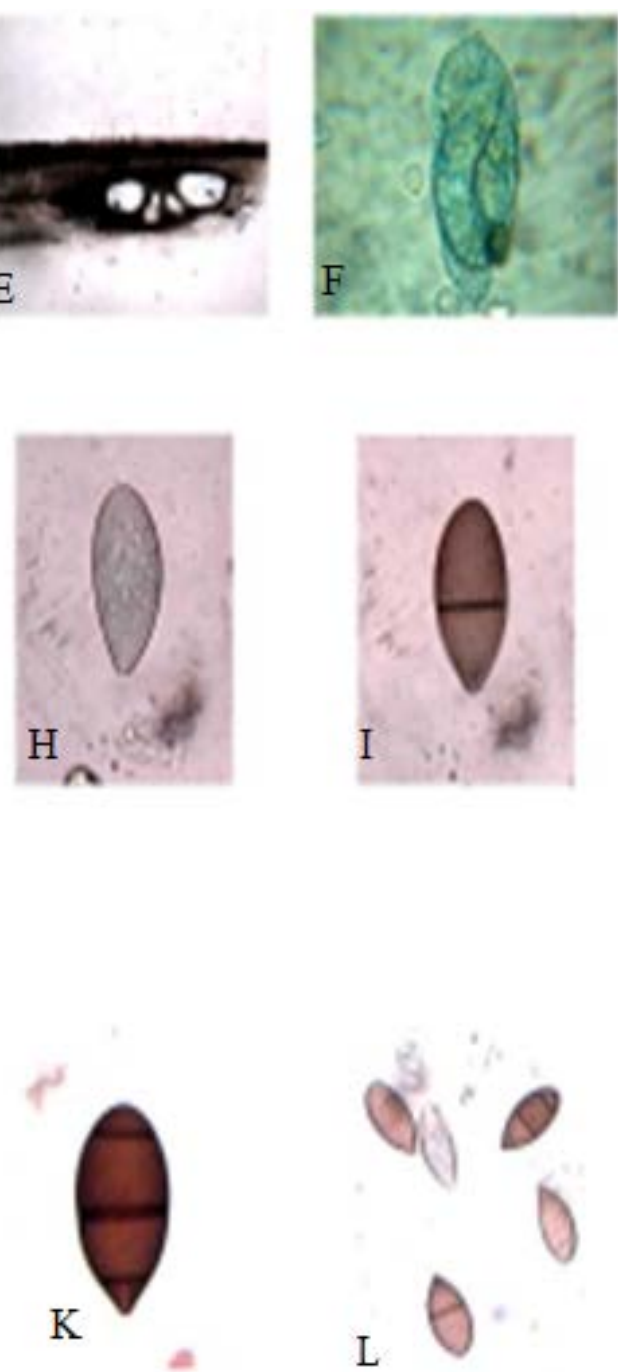

Fig. 2 - Paoayensis aquatic (HCIO 52061, holotype). D Habitat on submerged wood showing release of ascospores in cirrhus (arrowed). E V.S. of Ascomata showing ascoma in valsoid group. F Immature ascus. G Immature and mature asci. H Immature one-celled ascospore. I Immature 1septate ascospore showing basal germ slit (arrowed). J Mature 3-septate ascospore. K Mature 3septate ascospore showing basal germ slit (arrowed). L Immature and mature ascospores.

Table 1 Comparison of morphological characters of Paoayensis species.

\begin{tabular}{lll}
\hline & \multicolumn{1}{c}{ Paoayensis lignicola } & \multicolumn{1}{c}{ Paoayensis aquatica } \\
\hline Ascomata & Ascomata: $546-626 \mu \mathrm{m}$ high, $520-$ & $700-1000 \mu \mathrm{m}$ high, $800-1000 \mu \mathrm{m}$ \\
& $586 \mu \mathrm{m}$ diam. & diam. \\
Asci & $45-130 \times 13-35 \mu \mathrm{m}, 2-6$-spored & $85-170 \times 40-65 \mu \mathrm{m}, 8$ - spored \\
Ascospores & $41.9-79.9 \times 67-74.4 \mu \mathrm{m}$ & $50-80 \times 20-38 \mu \mathrm{m}$ \\
Reference & Cabanela et al. $(2007)$. & Present study \\
\hline
\end{tabular}

\section{Acknowledgements}

We wish to acknowledge the generous cooperation of Hon'ble authorities of management and Principals of our respective colleges for providing the numerous facilities to enable us to continue the research. Thank are due to the authorities of Smithsonian Tropical Research Institute, Washington DC, USA for providing pd files of research articles / papers on freshwater fungi. 


\section{References}

Bao DF, Luo ZL, Liu JK, Bhat et al. 2018 - Lignicolous freshwater fungi from China III: Three new species and new record of Kirschsteiniothelia from northwestern Yunnan Province. Mycosphere 9, 755- 768.

Baschien C, Hyde KD. 2018 - Special issue on freshwater ascomycetes and other aquatic fungi. Mycological Progress 17, 509-510.

Borse BD, Borse KN, Chaudhary SA, Patil VR et al. 2017 - Freshwater and Marine Fungi of India. LAP Lambert Academic Publishing, Germany.

Borse BD, Patil SY, Patil VR, Pawara CM, Borse KN. 2014 - Checklist of freshwater Ascomycetes in India. Journal Mycopathology Research 52, 279-284.

Borse BD, Tuwar AR, Patil VR, Pawar NB et al. 2016 - Aquatic Ascomycetes from India: The genus Savoryella. Science Park Research Journal 3, 1-5.

Cabanela MV, Jeewon R, Hyde KD. 2007 - Paoayensis lignicola gen. et sp. nov. Cryptogamie Mycologie 28, 303-310.

Cai L, Hyde KD, Tsui CKM. 2006 - Genera of freshwater fungi. Fungal Diversity Press, Hong Kong, China.

Cai L, Hu DM, Liu F, Hyde KD, Jones EBG. 2014 - The molecular phylogeny of freshwater Sordariomycets and discomycetes. In: Freshwater Mycology and Fungal-Like Organisms. Walter de Gruyer, GmbH, Berlin, Germany.

Li WL, Luo ZL, Lin JK, Bhat DJ et al. 2017 - Lignicolous freshwater fungi from China I: Aquadictyospora lignicola gen. et sp. nov. and new record of Pseudodictyosporium wauense from northwestern Yunnan Province. Mycosphere 8, 1587-1597.

Lin JK, Lu YZ, Cheewangkoon R, To-Anun C. 2018 - Phylogeny and morphology of Helicotubeufia gen. nov., with three new species in Tubeufiaceae from aquatic habitats. Mycosphere 9, 495509.

Luo ZL, Hyde KD, Lin JK, Bhat DJ et al. 2018 - Lignicolous freshwater fungi from China II: Novel Dictyosetispora (Dictyosetisporaciacea) species from northwestern Yunnan Province. Mycosphere 9, 444-461.

Shearer CA. 1993 - Freshwater Ascomycetes. Nova Hedwigia 56, 1-33.

Shearer CA, Pang KL, Suetrong S, Raja HA. 2014 - Phylogeny of the Dothideomycetes and other classes of freshwater fissitunicate Ascomycota. In: Freshwater Mycology and Fungal-Like Organisms. Walter de Gruyer, GmbH, Berlin, Germany.

Vijaykrishna D, Jeewon R, Hyde KD. 2006 - Molecular taxonomy, origin and evolution of freshwater Ascomycetes. Fungal Diversity 23, 351-390.

Wong MKM, Goh TK, Hodgkiss IJ, Hyde KD et al. 1998 - The role of fungi in freshwater ecosystems. Biodiversity and Conservation 7, 1187-1206.

Zhang H, Dong W, Hyde KD, Maharachchikumbura SSN et al. 2017 - Towards a natural classification of Annulatascaceae - like taxa introducing Atractosporales ord. nov. and six new families. Fungal Diversity, 85, 75-110. 